\title{
PEOPLE MANAGEMENT AND ITS IMPLICATIONS FOR THE INCLUSION OF PEOPLE WITH DISABILITIES (PWD) AT WORK: A STUDY IN A MATTRESS FACTORY LOCATED IN SOUTHEASTERN BRAZIL
}

\author{
Lucas Alves de Oliveira Lima ${ }^{1}$, Jorge Alberto Veloso Saldanha ${ }^{2}$, Paulo Lourenço Domingues Junior ${ }^{3}$ \\ $\varangle$, Matheus Alves de Oliveira Lima ${ }^{4}$, Gabriela Halfeld Barros Duarte ${ }^{5}$
}

\begin{abstract}
1,4,5 Undergraduate student in Administration at the Federal Rural University of Rio de Janeiro (UFRRJ), Brazil ${ }_{2}^{2}$ Graduated in Administration from Universidade Federal de Santa Catarina (UFSC/1999); Master in Administration from UFSC/2004; PhD in Production Engineering from UFSC/2009. Associate Professor - II, Federal Rural University of Rio de Janeiro (UFRRJ), Brazil

${ }^{3}$ Graduation in Administration from Universidade Católica de Santos (1994) and in Social Sciences from Universidade de São Paulo (2000); Master in Administration from Universidade Católica de São Paulo (1998); PhD in Sociology from Universidade de São Paulo (2006). Associate Professor - II, Universidade Rural do Rio de Janeiro (UFRRJ), Brazil
\end{abstract}

\begin{abstract}
Received 15 September 2021
Accepted 15 October 2021

Published 31 October 2021
\end{abstract}

\section{CorrespondingAuthor}

Paulo Lourenço Domingues Junior, pldominguesjr@uol.com.br

DOI

10.29121/granthaalayah.v9.i10.2021 .4332

Funding: This research received no specific grant from any funding agency in the public, commercial, or not-for-profit sectors.

Copyright: (C) 2021 The Author(s). This is an open access article distributed under the terms of the Creative Commons Attribution License, which permits unrestricted use, distribution, and reproduction in any medium, provided the original author and source are credited.

\section{ABSTRACT}

In the 1970s, social inclusion became a ubiquitous issue in the global scenario and professionals in the field of People Management began to adopt strategies for the inclusion of people with disabilities (PWD) in the labor market. However, currently, many organizations still face difficulties in hiring PWD, not adopting an effective inclusion, despite being provided for in Law number 8,213 of July 24, 1991 (Law of Quotas for PWD). Given this fact, the objective of this research was to analyze how Law number 8,213 is being applied in a mattress factory located in the city of Três Rios/RJ. This is research of qualitative approach, which was conducted through an in-depth interview with the manager of the People Management area, through a questionnaire based on the Model of Campos et al. (2013). To carry out the data analysis, it was used the content analysis technique according to Bardin (1977). As a result of the research, it was found that the factory does not perform as a strategy of People Management an effective inclusion program for the PWD, since practices are not developed to facilitate accessibility, retention and awareness of such individuals in the workplace. It is concluded that the admission of PWD is made tied to the legal obligation, i.e., for the mere fulfillment of the minimum percentage required by Law number 8,213. In this sense, the adoption of palliative strategies prevails in the factory so that people with disabilities are only inserted into the workplace.

Keywords: People Management, Law Number 8,213 (Quotas Law), People with Disabilities, Mattress Factory, Três Rios (Rj)

\section{INTRODUCTION}

The vision of exclusion in relation to people with disabilities (PWD) has persisted in society over time and, above all, in the admission for entering the labor market. In the past, these individuals were considered as simple objects of medical intervention or charity, and not as holders of rights and duties Schwarz et al. (2009).

According to Gaudenzi and Ortega (2016), it was with the advent of social movements in the 1970s that the pressure around the inclusion of groups historically excluded from privileges began to gain notoriety. In this context, 
changes in organizational management occurred and professionals in the area of people management began to have to deal with a new paradigm, thus developing strategies to ensure that PWDs are able to develop their potential within companies. Since then, the issue has been gaining increasing prominence in the global scenario and, consequently, raising a debate on the regulation of laws directed to guarantee the rights of PWD at work.

In Brazil, following such claims, the 1988 Constitution ensures in the principles, through Federal Law number 8,213, published in the Official Gazette of the Union (D.O.U) on July 14, 1991, the mandatory hiring of employees (with some degree of deficit or disability) for organizations that have more than 100 workers. However, authors such as Campos et al. (2013) point out that the enactment of Law number 8,213 generated numerous discussions, both in the academic environment and in the business environment, since managers still find it difficult to hire and implement measures that would be necessary for an effective inclusion.

Data from the Annual Social Information Report of the Ministry of Labor for 2018 showed that only $1 \%$ of all vacancies in the formal Brazilian market were filled by PWD in the private sector, while the occupation rate of PWD in the public sector was $0.4 \%$. It is evident, then, a panorama of considerable social vulnerability in a country where $6.7 \%$ of the active population has some degree of disability, whether physical, mental, or hearing limitations Ibge (2018).

Given this scenario, the article in question had as its main objective to analyze whether the managers of a mattress factory that must comply with Law number 8,213 (Quotas Law), a company located in the municipality of Três Rios (RJ), carry out some strategy for the inclusion of PWD in its team of employees. In addition, it is sought to verify whether the company management adopts the main items proposed in the Model of Campos et al. (2013).

The model of Campos et al. (2013) addresses eight criteria (which must exist) so that an effective inclusion program is efficient, being them, the analysis of accessibility; the analysis and definition of the profile of the professional with disabilities; awareness; the recruitment and selection; the evaluation of occupational health; the training; the career development and promotion; and finally, the retention of the employee. It is expected that the results of this research bring contributions that can provide theoretical and practical subsidies related to the increase of hiring PWD in the labor market.

\section{THEORETICAL FRAMEWORK 2.1. PEOPLE WITH DISABILITIES (PWD)}

The bearers of a body marked by difference were, according to Gaudenzi Ortega and (2016), designated as invalids and degenerates (in the past) in Western culture, because anomaly was seen as a "Punishment from the Gods". In the Modern Age, with the emergence of the biomedical narrative over the religious discourse, the perspective of anomaly as a divine punishment started to deteriorate. Since then, disability is characterized as a field of debate worldwide.

Fávero (2007) adds that an individual can be considered as disabled if he/she has some mental, hearing or physical restriction that prevents him/her from performing activities of daily living. Other authors, such as Palacios and Romañach (2006), highlight that disability is a body functional diversity, which involves a personal identity characteristic.

In this sense, Schwarz and Haber (2009) inform that the concept of person with disabilities is broad and covers a set of characteristics, and, although the term used 
is person with disabilities, it would be advisable to identify the person by his or her birth name. The limitation of the person with disability (PWD) may be acquired in the course of life or be with them since birth, and may be permanent or not.

For the types of disabilities, Decree number 3,298, art. 04:

1) physical disability: Complete or partial alteration of one or more segments of the human body, resulting in impairment of physical function, presenting itself in the form of paraplegia, paraparesis, monoplegia, monoparesis, tetraplegia, tetraparesis, triplegia, triparesis, hemiplegia, hemiparesis, ostomy, amputation or absence of limb, cerebral palsy, dwarfism, limbs with congenital or acquired deformity, except for aesthetic deformities and those that do not produce difficulties for the performance of functions (Decree n0 5.296, of 2004);

2) Hearing impairment: partial or total bilateral loss of forty-one decibels $(\mathrm{dB})$ or more, measured by audiogram at $500 \mathrm{~Hz}, 1,000 \mathrm{~Hz}, 2,000 \mathrm{~Hz}$ and $3,000 \mathrm{~Hz}$ (Decree No. 5,296 of 2004);

3) Visual disability: blindness, in which the visual acuity is equal to or less than 0.05 in the better eye, with the best optical correction; low vision, which means visual acuity between 0.3 and 0.05 in the better eye, with the best optical correction; the cases in which the sum of the measurement of the visual field in both eyes is equal to or less than $60 \mathrm{o}$; or the simultaneous occurrence of any of the previous conditions (Decree no. 5.296, of 2004);

4) Mental Disability: intellectual functioning significantly below average, manifested before the age of eighteen and limitations associated with two or more areas of adaptive skills, such as: a) communication; b) personal care; c) social skills; d) use of community resources; e) health and safety; f) academic skills; g) leisure; and h) work (Decree n0.5.296, of 2004);

5) Multiple Disability: an association of two or more disabilities.

\subsection{INCLUSION PROGRAMS AND THE WELCOMING OF PWD IN THE ORGANIZATION}

The term inclusion refers to the action of inserting an individual or a group of individuals into society, without taking into consideration inner and outer aspects Schwarz and Haber (2009). The act of including is a human and fundamental act for the person being included, since this attitude can be considered the starting point of their contribution and of feeling useful to society Schwarz and Haber (2009).

Based on these aspects, the inclusion model for PWD seeks to promote equal opportunity for all when focusing on vacancies for the labor market, and an adequate process of inclusion of PWD will depend on a good planning Tanaka and Manzini (2005). In this perspective, one should take into consideration that this is probably the first contact of the person with disability with the institution. At this stage it can be observed if diversity and inclusion are values cultivated, or not, by the organization.

According to Tanaka and Manzini (2005), during this trajectory, all care should be planned and implemented, from the beginning of the recruitment process until the completion of the selection process and admission of the candidate, and several techniques can be applied in these processes of recruitment, selection and admission of candidates.

Schwarz and Haber (2009) point out that the condition to start a process of inclusion of PWD in the company involves the ability of its managers to prepare a 
process planning containing its various contractual stages. Therefore, as an initial idea of a reasoning regarding the inclusion of people with disabilities in the labor market, organizations should be concerned with seeking relevant information on the subject in order to achieve effective results.

From this perspective, Schwarz and Haber (2009) point out that "the legislation is important, but it is not enough for companies to include people with disabilities in their workforce with quality and consistency". For these authors, it is essential to train the organization managers, guide employees for the inclusion, invest in accessibility and monitor the people included until they are fully adapted to their work activities. Therefore, in its initial selection process, the organization must be prepared to receive the candidate and have a welcoming and accessible environment for the possible needs of the interviewees, whether they are hearing, physical and/or mental Schwarz and Haber (2009).

For Chiavenato (2017), the selection process will vary according to the type of decision to be made by the company. The author describes four models that can be used in the selection process of candidates, namely: Placement Model; Selection Model; Classification Model and Value Aggregation Model.

This author highlights that the Placement Model is characterized by having only one candidate for a single available position. Thus, there is no possibility of elimination of the individual during the selection process. As for the Selection Model, several candidates are evaluated for only one vacancy to be filled, and the admission is made according to the requirements demanded by the position.

In the third model mentioned by the author, i.e., the Classification Model, there are several vacancies and people who apply for the position. In this sense, if there is a failure of the candidate, the same may apply for other vacancies offered by the company. Finally, when adopting the Value Aggregation Model, managers seek to make a selection based on individual competencies in order to strengthen the organizational competitiveness Chiavenato (2017).

Schwarz and Haber (2009) point out that in the task of preparing a survey for filling specific vacancies to PWD, the professional responsible for the act must keep in mind that there is a standard to be adopted as a parameter. These authors recommend a dynamic or collective interview. Thus, there is the possibility of observing the candidate in a work situation and team coexistence. At this moment, one must not approach the disability issues and the implications it brings to the dayto-day life of the disabled person. The issues related to the candidate's limitations, preferably, must be treated in a private way, in order to avoid embarrassing situations. Also, for these authors, it is clear the degree of importance arising from a good management of PWD, since, after the hiring, the PWD will be directly acting as a collaborator in the organization.

Given the above, the company should already be prepared to receive new employees and have an understanding of certain limitations that PWD may face, so it can reduce unforeseen events and increase the effective results of these employees. In this case, so that there is a transformation and the inclusion of PWD is efficient, it is necessary to have an awareness of the company's top leadership and also of other employees who must be trained for the adaptation process in relation to PWD, understanding their profile, their specific needs, their expectations and their perceptions in the work environment Schwarz and Haber (2009).

As Freitas (2009) points out, including people in the labor market is a learning process, since the professional of people management plays an important role in the inclusion of the PWD and the organization will have to adapt according to their needs, constantly encouraging their development. 
According to Chiavenato (2017), the retention of employees with disabilities is associated with actions aimed at keeping workers in organizations, even because the PWD need a reasonable amount of time in the company to demonstrate their skills and competencies in the course of employment and, therefore, they can advance in their careers.

Regarding the welcome within the organization, the authors, Campos et al. (2013) point out that for there to be an awareness around PWD, it is essential that the co-workers of PWD have knowledge of the limitations of these employees, because it is recommended the welcome of these people with disabilities by their co-workers. This should occur to facilitate the process of inclusion of the PWD and contribute to solve any problem that may arise in the work routine.

Perform a differentiated training for PWD is important within the organization, as highlighted by Chiavenato (2017). Training is a systematic process that aims to provide learning opportunities and behavioral changes, and with this, stimulates workers to be more productive to generate a better result. An efficient training directed to PWD improves the reception and, consequently, makes the PWD perform their work better, thus increasing the retention of these people in the organization.

\subsection{THE MODEL OF CAMPOS, VASCONCELLOS AND KRUGLIANSKAS (2013)}

The Model of Campos et al. (2013) describes the main components of the practices of PWD Inclusion Programs. The model was created based on what scientific knowledge describes as important for the inclusion of PWD in companies, having as a guideline the planning process of the Secretariat of the Person with Disabilities and Reduced Mobility (SMPED) in 2008 and the theoretical reference of articles and books of researchers who address the topic in question. The Model is divided into eight topics that are detailed in Table 1.

According to the Model of Campos et al. (2013), the company must make an analysis of accessibility, where there must be in the inclusion of people with disabilities the guarantee of autonomy and accessibility to facilities and equipment. In addition, it should be performed an analysis and definition of the profile of PWD so that it is possible the adequacy of tasks. It is important to focus on the potential of each individual, instead of focusing only on the disability and to avoid the concentration of PWD in one or more sectors of the company.

Regarding awareness, the model mentions that the person in charge of the People Management area should promote the interaction of employees, regardless of whether or not they have disabilities, as well as conduct training with employees who interact or are leaders of PWD.

To carry out the recruitment and selection processes, it is suggested the use of partner institutions that have expertise with PWD in these activities. The selection process should be based on the skills and competencies of each individual in a particular way Campos et al. (2013).

\begin{tabular}{|c|c|}
\hline \multicolumn{2}{|c|}{ Table 1 Model of Campos et al. (2013) } \\
\hline $\begin{array}{l}1 \text { - Accessibility } \\
\text { analysis }\end{array}$ & $\begin{array}{c}\text { Guaranteeing autonomy; adapting the accessibility of facilities and } \\
\text { equipment; and universal design. }\end{array}$ \\
\hline $\begin{array}{l}2 \text { - Analysis and } \\
\text { definition of the } \\
\text { PWD profile }\end{array}$ & $\begin{array}{l}\text { Non-concentration of PWD in only one or a few areas of the company; } \\
\text { adequacy of tasks; and focus on potential instead of focusing only on } \\
\text { disability. }\end{array}$ \\
\hline
\end{tabular}




\begin{tabular}{|c|c|}
\hline $\begin{array}{l}3 \text { - Awareness } \\
\text { Raising }\end{array}$ & $\begin{array}{l}\text { Promotion of interaction and coexistence between people with and } \\
\text { without disabilities; training aimed at raising awareness of PWD } \\
\text { colleagues and leadership. }\end{array}$ \\
\hline $\begin{array}{l}4 \text { - The recruitment } \\
\text { and selection } \\
\text { process }\end{array}$ & $\begin{array}{l}\text { Use of organisations that deal with people with disabilities as partners for } \\
\text { the recruitment and selection process based on competences and skills. }\end{array}$ \\
\hline $\begin{array}{l}5 \text { - Occupational } \\
\text { health assessment }\end{array}$ & Realization of the evaluation. \\
\hline 6 - Training & $\begin{array}{l}\text { Equal opportunities regarding access; accessibility } \\
\text { (architectural/communication); and expectation in contributing to expand } \\
\text { the career possibilities for PWD. }\end{array}$ \\
\hline $\begin{array}{l}\text { 7- Career } \\
\text { development and } \\
\text { promotion }\end{array}$ & $\begin{array}{c}\text { Equal opportunities regarding access; existence of performance criteria } \\
\text { adapted to adequate performance standards; charging for PWD } \\
\text { performance; and provision of information about promotion } \\
\text { opportunities. }\end{array}$ \\
\hline 8 - Retention & Commitment of PWD and search for reduction of high turnover costs. \\
\hline
\end{tabular}

Regarding occupational health, the authors emphasize that there must be an evaluation with PWD and that training must occur with equal opportunities for all, with the right to have a career plan, architectural accessibility and access to business communication.

Finally, the last two topics addressed are related to retention and career development, where there should be promotions. Retention refers to the search for commitment and the reduction of turnover of PWD, and to combat this effect, one can use as a strategy the adoption of a "Career Plan" with the adoption of promotions and performance collection criteria in an appropriate way.

\subsection{THE QUOTAS ACT FOR PEOPLE WITH DISABILITIES (LAW NUMBER 8,213)}

Established in Brazil on July 24, 1991, the Federal Law number 8,213 (Quotas Law for PWD) ensures the habilitation, rehabilitation and gives the PWD the necessary means for reeducation and professional readaptation, with the goal that these people can be part of the labor market Schwarz and Haber (2009).

For Neves-Silva et al. (2014), the Federal Law number 8,213 benefits the PWD through the mandatory inclusion of these people in the labor market, however, the legislation alone is not able to promote inclusion broadly. As the authors point out, "it is necessary to raise awareness of the population about the real limitations and potential of these individuals" Neves-Silva et al. (2014). Also, for these authors, awareness should be comprehensive and focused on the whole community, since all people are subject to acquire a disability or interact with them.

The Quotas Law requires organizations to have a minimum percentage of PWD in their workforce, which varies according to the total number of employees of the company. Theoretically, Federal Law number 8,213 was created with the idea of ensuring equal rights for PWD, but in practice there are factors that hinder the application of the law. These are factors that need to be taken into account, such as the level of preparation (both professional and social) of disabled people who seek insertion in the labor market, as well as the conditions (structural, functional and social of the organizational environment) that the employee with disabilities will be subject to receive Tanaka and Manzini (2005). 
Table 2 details the value of the percentage in relation to the total number of employees of the organization Brazil (1991).

\begin{tabular}{|cc|}
\hline Table 2 Minimum mandatory percentage of PWD by total number of employees \\
\hline Total Number of Employees in the Organization & Percentage \\
\hline Up to 200 employees & $2 \%$ \\
From 201 to 500 employees & $3 \%$ \\
From 501 to 1000 employees & $4 \%$ \\
Above 1000 employees & $5 \%$ \\
\hline
\end{tabular}

Lancillotti (2003), highlights that "the least absorbed are, precisely, people with intellectual disabilities, who have greater difficulties in achieving schooling compatible with the rules of the contemporary market. In practice, Law number 8,213 has contributed to the employability of a portion of the PWD population, but this author reiterates that this law has become an instrument of claim and that only this legal tool is not enough to solve all the problems faced in the process of inclusion of PWD in the labor market.

For Tanaka and Manzini (2005), the first steps have already been initiated, but still, in many companies, the insertion occurs by the imposition of Law number 8,213 and hiring PWD just for a mandatory legal issue, without removing other obstacles in the way, will only strengthen the stigma that PWD do not have skills and abilities to perform tasks that can keep them in the labor market.

\section{METHODOLOGY}

Regarding the method, the research was characterized as exploratory of qualitative approach. According to Godoy (1995), when a qualitative approach is used, the "phenomenon can be better understood in the context in which it occurs and of which it is part" and must be analyzed in an integrated perspective.

In this type of approach, the researcher goes into the field to collect data and then conducts an analysis of these data, considering all points of view so that it is possible to understand the dynamics of the phenomenon. The procedures of this approach include observations, analysis, interviews and bibliographic survey Godoy (1995).

To conduct the research (initially) it was necessary to contact the Três Rios (RJ) municipal government to map which companies would be included in Federal Law number. 8,213. In a second step, there was a referral to the Labour Coordinator of the city hall who provided a list of organisations included in this Law and which were located in the aforementioned municipality. In the list there was, among other companies, a mattress factory. The criterion for choosing the mattress factory was performed using convenience sampling, which is characterized by a nonprobabilistic sample, i.e., devoid of statistical calculations. Thus, the selection in this type of sampling was made according to the availability and accessibility of researchers in relation to the element to be studied Malhotra (2001).

In a third step, the manager of the mattress factory was contacted to request an appointment to conduct the in-depth interview. The request was immediately accepted, quickly enabling the scheduling of data collection for the study. In the fourth stage, for the preparation of the research instrument, it was used as a basis the Model of Campos et al. (2013). The questionnaire was adapted and divided into 
two parts, the first part characterized by questions about people with disabilities and the second by questions related to the inclusion of PWD.

After the questionnaire in its first version was finalized, a first pre-test was conducted with the manager of People Management of the plant in order to improve data collection, ensure the accuracy and guarantee the clarity of the terms. The registration occurred in September 2019 through a semi-structured interview. The research instrument had twenty-three questions (closed and open) previously defined Boni et al. (2005).

As a result of the pre-test, seven questions were discarded and the final version of the questionnaire had only open questions, that is, the final version of the questionnaire resulted in an in-depth interview guide. After the changes, there was no need to conduct a next pre-test, ending this process of adjustment of the research instrument.

Given the changes, it was scheduled a new meeting with the Manager of the People Management sector of the organization for data collection. Thus, the data collection was carried out by applying an in-depth exploratory interview which, according to Boni et al. (2005), aims to obtain detailed information about a particular phenomenon, where the interviewer introduces the theme and the respondent has freedom to discuss the subject. The interview lasted forty-seven minutes and occurred in November 2019.

In addition to data collection, it was also chosen to perform participant observation, where, "it is combined at the same time the active participation with the subjects, intensive observation in natural environments, interviews and analysis" Moreira (2002). For better accuracy in the data collection process, the interview was recorded in full and later transcribed, thus facilitating their analysis. All questions were answered, without exception.

Regarding the analysis of the results, the content analysis technique was used. According to Bardin (1977), content analysis is a set of methodological tools that aims to identify the message content in a systematic way through three steps: preanalysis, material exploration and treatment of results.

According to the author, pre-analysis is the phase in which the material is organized for the systematization of the initial ideas. Thus, there was the construction of the theoretical framework through scientific articles and books that address the theme PWD. To this end, readings were performed, documents were chosen and the material was prepared. After the completion of the first phase, we proceeded to the exploration of the material with the textual clippings in units of records. In this sense, data collection was carried out in the plant with the application of the questionnaire based on the model of researchers in the area (item 2.3). Subsequently, the treatment of the results took place taking into account the theory addressed in this research, using the process of coding and categorization of the results that were aggregated to facilitate the description and analysis of the results.

It is important to highlight that the interview recording (data collection) was authorized by the respondent. Subsequently, the transcript was sent by e-mail to the interviewee, for adjustments, if necessary. After reading all the transcripts of the interview, the respondent informed the researcher that adjustments in the transcripts would not be necessary. The respondent requested only to maintain the anonymity of the organization. 


\subsection{CHARACTERIZATION OF THE RESEARCH SITE}

The factory in which the research was conducted is of a Rio de Janeiro brand in the mattress segment. The brand operates in the market since 2005, providing mattresses with the purpose of providing comfort conditions to its customers and developing technological innovations in order to innovate in products, according to the needs and trends of the consumer market.

In the factory, several types of mattresses are produced, being the most common, the spring type, which is made of internal springs with an upholstered cover. In addition, there is the manufacture of mattresses that are made of foam, air and water. Although the production focus is on mattresses, a considerable part of the factory's production is dedicated to the manufacture of related products such as boxes, armchairs, headboards, springs and foams. The land where the company is installed has an area of $35,000 \mathrm{~m}^{2}$, of which $5,000 \mathrm{~m}^{2}$ is destined only for the storage of these other products, which are not mattresses.

After production in the industry, the mattresses and other related products already mentioned, are distributed to over 50 own brand stores in Brazil and also to other partner companies that resell these products contributing to the retail distribution process. The plant is inserted in the Quotas Law for PWD (Federal Law number 8,213) and is located in the city of Três Rios (RJ) in the neighborhood Cantagalo. The municipality is located in the interior of the state of Rio de Janeiro, in the Sul-Fluminense region and is part of the industrial axis of the cities near the BR-040 and BR-393 Ibge (2018).

\section{RESULTS AND ANALYSES}

In this topic, it will be presented the results of the research that covers the description and analysis of the data collected, which were divided into three topics. The first topic exposes information regarding the PWD working at the plant (4.1), the second topic is related to the inclusion programs of PWD in the company (4.2) and the third topic (4.3) refers to the difficulties encountered by the company for hiring PWD.

\subsection{PEOPLE WITH DISABILITIES IN THE FACTORY}

The first part of the questionnaire aimed to identify whether the factory complies with the Federal Law number 8,213 (Quotas Law), as well as aimed to obtain information about the PWD. In this sense, it was asked about the number of employees of the plant and how many of them have some kind of disability, as shown in Table 1.

According to the results presented in Table 03, in the company there are 156 hired workers and four of these employees have some type of disability. Thus, it is noted that the factory meets (in minimum quota) the Federal Law number. 8,213 (Quotas Law) by allocating 2\% of vacancies for PWD. 


\begin{tabular}{|ccc|}
\hline Table $\mathbf{3}$ Classification of company employees in relation to Law number 8,213 \\
\hline Collaborators & Absolute frequency & Percentage (\%) \\
\hline No disability & 152 & 97,44 \\
\hline Disabled & 4 & 2,56 \\
\hline Total & 156 & 100,00 \\
\hline
\end{tabular}

Source: Survey data (2019)

Subsequently, in order to obtain more information related to the PWD working in the company, it was asked what type of disability and what position these employees hold in the organization. This information is detailed in Table 4.

\begin{tabular}{|c|c|c|}
\hline PWD & Deficiency & Position \\
\hline PWD1 & Visual & Production operator \\
\hline PWD2 & Visual & Production operator \\
\hline PWD3 & Auditory & Young apprentice \\
\hline PWD4 & Physics & Production assistant \\
\hline
\end{tabular}

Source: Survey data (2019).

Observing Table 4, it was found that two employees have visual disabilities (PWD1 and PWD2); one employee has hearing impairment (PWD3) and one employee has physical disability (PWD4). Given the data obtained, it is possible to ascertain that there is no employee with mental disabilities. This fact corroborates the theory, since the mentally disabled have the lowest percentage of hiring by the companies. The results of the research also showed that, in relation to the activities performed by the PWD, their functions are: the physically disabled person occupies the position of production assistant; the hearing-impaired person is a young apprentice; and the other two visually impaired people are production operators. The results show that in this company the PWD do not occupy leadership or management positions, i.e., they do not occupy positions in the high hierarchy of the organization.

\subsection{INCLUSION PROGRAMMES}

\subsubsection{RECRUITMENT AND SELECTION OF PWD}

Regarding the recruitment and selection process of PWD, it was possible to verify that it is performed by professionals in the People Management area and has the same characteristics as the recruitment and selection processes of individuals without disabilities, except for some specific procedures.

The first stage of the recruitment of PWD at the plant begins with the disclosure of the vacancy at the Association of Parents and Friends of Exceptional Children (APAE) and the Social Service of Industry (SESI). Thus, when it was asked if there were any agreements with institutions to facilitate the recruitment process of PWD, it was found that there are partnerships with APAE and SESI, corroborating what the model of Campos et al. (2013) provides. It is observed that, in the case of PWD, external recruitment prevails (which requires a disclosure of opportunities to the market), not offering opportunity for career advancement for workers with disabilities in the company, which would occur in internal recruitment. 
After the external recruitment, the stage of selecting candidates takes place. In the factory, the model used is the Selection Model (described in item 2.2), since it involves several candidates for the position with only one vacancy to be filled. In this logic, the candidates are compared with the requirements demanded by the position, and they may be approved or rejected. For the evaluation, techniques such as interview and resume analysis are used, being the selection based on competencies and skills.

During the selection process, PWDs are treated and evaluated in the same way as other candidates without disabilities in the selection process. Currently, of the four employees with disabilities working in the company, only two come from a recruitment and selection process. The other two were factory workers and were referred to the doctor at the request of the manager of the company's people management department, in order to be categorized as PWD. The interviewee's results showed that, due to the difficulty faced in hiring PWD, it was necessary to do so so that the factory could meet the requirements of Law number 8,213.

In view of this fact, we should point out that there should be a recruitment and selection process linked to the perception of inclusion and not the categorization of former employees as PWD, due to mere concern with the legal obligation. This corporate attitude only strengthens the prejudice that the PWD do not have labor competence, which may lead to difficulties regarding the accessibility of the disabled to work in a dignified manner.

\subsubsection{ACCESSIBILITY FOR PWD}

After the recruitment and selection processes, the selected individuals start working in the company. Thus, for the effective inclusion of PWD, there must be an accessibility for these employees in the workplace. During the interview it was asked whether the plant had some kind of adaptation of facilities and equipment to receive PWD. From the results obtained, it was observed that there was no adaptation, because according to the respondent, there would be no need since the management of people of the company considers PWD as normal people.

Although these people are considered normal, it is necessary to be aware that PWD have special needs. It is important to note that the inclusion of PWD presupposes architectural (and ergonomic) accessibility and the ability to receive individuals with all types of disabilities, a capacity that should be emphasized because the factory is included in Law No. 8,213. In the research, it was possible to verify, for example, that there is no infrastructure in the factory capable of receiving people who need wheelchairs, since there are no ramps in the work space. In addition, there are no tools in the work environment to help PWD with their respective physical limitations of displacement, among others.

Following the research, it was sought to verify if the factory aims to provide communication accessibility. The results show that there are no means to assist the hearing or visually impaired, that is, there is no kind of instructions in libras or Braille to help the PWD in the business communication process. Regarding the level of allocation of employees in the various departments of the company, it was found that the PWD are not concentrated in only one production sector, and yes, they are distributed by the factory according to the production needs, i.e., employees with disabilities can act in all sectors of the organization.

As a result of the research, it was also observed that there is no adequacy of the activities related to PWD, showing that these employees go through an entry process equal to workers who do not have disabilities. In the company's view, there 
is no need for any kind of adaptation for PWD, corroborating apparently for a system of insertion in which PWD are part of the organization without the necessary adaptations, which is not suggested by researchers in the area (item 2.2). To obtain a fully inclusive and conducive environment that offers comfort and adaptation to PWD, several factors must be taken into account as already highlighted in the theoretical framework (item 2.2).

In this bias, it is verified that the organization in question does not offer an adaptation in facilities and equipment for use of PWD. The research showed that there are still difficulties that have not been fully resolved, being performed only palliative strategies with small changes in the work environment, which does not fully meet the needs of PWD, because for the company to include employees with limitations, it is necessary that it has healthy conditions and the necessary infrastructure to receive them.

\subsubsection{RETENTION OF PWD IN THE ORGANIZATION}

With respect to the retention of PWD in the organization, it is observed that, as detailed in Table 5, employees with disabilities have been working in the company for a short time. That is, none of the PWD cited in the survey has been working at the plant for more than two years, since the time of their hiring. The results show that there is a low retention of employees with disabilities, since the hiring time is not high.

\begin{tabular}{|c|c|}
\hline \multicolumn{2}{|c|}{ Table 5 Working time of PWDs in the company since they were hired } \\
\hline PWD & Working time of PWDs in the company \\
\hline PWD1 & One and a half years \\
\hline PWD2 & Two years \\
\hline PWD3 & Six months \\
\hline PWD4 & Three months \\
\hline
\end{tabular}

It is observed that the working time of PWD in this company varies from three months to two years, and half of these employees have not even completed one year of employment contract.

In the case of the organization in question, it is possible to ascertain that the turnover rate in the company is considerable due to the low retention of PWD in the factory. This fact was highlighted in the research, because the manager of the people management department, when asked about the high turnover rate (in relation to PWD), reported that this fact is associated with the local city, i.e., that the city of Três Rios (RJ), where the company is located, has a culture that employees do not stay long in their jobs. However, the manager of people management highlighted in the interview that this has been changing over time and that these considerable rates of employee turnover in the city have been decreasing over time.

It appears that in the last 10 years, the municipality of Três Rios (RJ) received many industries and service companies (hotels, restaurants, among others), which has caused the average turnover rate has been reduced in the municipality over time. Before that, there was a great predominance of the trade sector, conducive to low employee retention. Consequently, this currently impacts the retention of PWD in factories of the municipality, because many employees still prefer to follow the branch of commerce, for being a sector already consolidated in the region. 
The expansion of the industrial sector in Três Rios (RJ) began in 2009, when the City of Três Rios (RJ) granted tax incentives for entrepreneurs who set up industries in the municipality. The incentives involved exemption from $100 \%$ of the Property Tax (IPTU) for 25 years; reduction of the Tax on Services of Any Nature (ISS) to 2\%; exemption from the construction tax; creation of a Development Company linked to the Department of Industry; and the facilitation of the Government in the expropriation of areas with housing subsidies.

Regarding the departure of PWD from the factory, it could be understood that there is a dismissal by initiative of the employee, because employees with disabilities often decide, for personal reasons, to resign due to the search for employment in commerce. The research results show that many PWD decide to quit their jobs due to the Continuous Cash Benefit (BPC), a benefit offered by the Federal Government directed to PWD. Thus, the dismissals occur most of the time by initiative of the workers.

\subsubsection{CAREER DEVELOPMENT AND PROMOTIONS OF PWD WITHIN THE ORGANIZATION}

Regarding the career development and promotion of PWD within the company, it was asked whether the organization offers this possibility to its employees with disabilities. The manager's response was positive, emphasizing mainly the effort of the employee, i.e., over time the PWD, by improving their skills and performance with the work, will cause the company to offer an enrichment of position, with increased remuneration in relation to the previous position held by the PWD.

When analyzing the data obtained in the interview in the context of career development and promotion of PWD in the company, the results show that the organization adopts a discourse of offering the same opportunities for promotion and career advancement equally to all its employees, whether they are PWD or not. The company disseminates and makes available promotion opportunities (internal recruitment) and the performance requirements, skills and competencies needed for new opportunities for all its employees. The manager of the people management area highlighted in the interview that this is the organization's policy, and the PWDs who are developing and committed to the work will receive more attractive proposals and rise in the organization like any other hired employee.

The results of the research showed that the two production operators who were hired as assistants later rose to more complex positions, i.e., were promoted, due to the excellent performance they achieved in the previous position. However, it is noteworthy that the low retention evidenced in the results (item 4.2.3) is a factor that hinders the possibility of career development and promotion of PWD in the organization as already highlighted in topic 2.2 .

\subsubsection{AWARENESS OF THE COMPANY IN RELATION TO PWD}

In relation to this issue, we sought to find out if the company adopts strategies for interaction and coexistence between PWD and other employees. The results showed that awareness in the company is not performed satisfactorily, since workers without any kind of disability have no knowledge of who are the employees classified as PWD and neither the type of disability they have. The people management manager pointed out that in the company all employees interact equally among themselves and they do not know that there are among them, employees with some kind of limitation. It is observed, therefore, that the strategy 
used by the organization is not corroborated by what the theory on the subject suggests, as highlighted in item 2.2.

The people management manager was questioned about his perception regarding the presence of PWDs working in the organization. The manager pointed out that at first, he had a bad perception in relation to PWD, however, over time he realized that these actions contribute a lot to social inclusion (of PWD) and that currently it is essential to seek an egalitarian society. The people management manager had a general perception of PWD, imagining that they would not be competent in performing their work, generating problems in the organization's production line, but currently the interviewee no longer has this perception. Today, his perceptions are different, believing that a PWD may have some kind of loss, but that this does not interfere with the quality of his work, depending on this quality much more on the dedication of the employee in relation to his task than on his physical limitation.

\subsubsection{TRAINING AND ASSESSMENT OF THE OCCUPATIONAL HEALTH OF PWD}

Regarding the training of PWD in the organization, these are carried out in two ways, namely: a) motivational training; and b) technical training. It was observed by the research results that in the company the trainings are not associated with the awareness around the PWD. The trainings are common to all employees of the organization, with no differences, i.e., they are generalist and are not aimed at supplying issues faced by employees who have some kind of limitation.

This strategy is not corroborated by the theory described (item 2.2), since in the factory the trainings performed are generic and not directed to PWD. Without conducting training as suggested by researchers in the area, the company has its social approach compromised in part, because with training aimed at raising awareness of PWD, the behavioral change of workers and their performance could be developed more effectively.

Regarding the occupational health of PWD, it was observed that health assessments are routinely made with these employees and thus, there is a concern of the company so that occupational diseases are prevented, since for PWD the pressure required at work can be a major aggravating factor in their health, due to the fact that they are more sensitive to the structural and social environment and the conditions provided to them.

\subsection{DIFFICULTIES IN HIRING PWD}

When addressing the issue of hiring PWD in the organization, it is observed that there is a certain degree of difficulty, one of the main ones being the difficulty of recruitment, because the partner institution, the Association of Parents and Friends of People with Special Needs (APFPS), does not have a database of PWD in their limitations and characteristics. APFPSN does not inform the company that there are candidates available for the disabled positions, despite the organization requesting this information.

In this context, the people management manager of the company suggested that the City of Três Rios could partner with the city's APFPS, creating an information bank with all the PWD in the municipality, thus facilitating the recruitment process of PWD for all companies located in the municipality Três Rios (RJ). 
Another difficulty is the loss of the Continuous Cash Benefit (CCB) by PWD if they are hired by the company. The benefit is offered by the Federal Government in order to guarantee a minimum wage for elderly people over 65 years old who prove to have no income and for individuals with a long-term intellectual, physical, mental, or sensory deficit, i.e., who have effects for at least two years.

According to the interviewee, many PWD do not want to work because they imagine they will lose the benefit offered by the Federal Government. However, these people do not know that the benefit cut only occurs during the time they are working. PWD believe that if they work in any organization in a registered manner, they will no longer have the right to the benefit until their death, which is not true, but it is a factor that hinders the recruitment of PWD.

The research results show that this perception of PWD provides a feeling of instability and insecurity before the possibility of entering the labor market. In practice, the Federal Law that supports the Continuous Cash Benefit (CCB) ends up being another barrier that hinders the hiring of PWD in organizations.

\section{CONCLUSION}

After the analysis of all the results of the research where a qualitative approach was used and that was conducted in a mattress factory located in the city of Três Rios (RJ), it was verified, by the reports of the manager of the people management area of the organization, that the company in complying with the Federal Law number 8,213 (Quotas Law), is more focused on obtaining legislative benefits than properly, to include the PWD in the labor market.

This result is evidenced in several points where some strategies (in the area of people management) used by the company are not corroborated by the strategies suggested by researchers in the area described in the theoretical framework of this article (topic 2).

One of the examples occurs when, in the contractual planning to sign a new employment contract with PWD, there is no effort from the organization to create a strategy to adapt PWD to the work environment, which goes against the existing theoretical basis on the subject. The factory should provide an inclusive and welcoming work environment to the needs of PWD in its entirety.

However, it is important to highlight that, due to the Continuous Cash Benefit (CCB) provided by law and also the fact that the Association of Parents and Friends of Exceptional Children (APFPS) is not structured to contribute to the recruitment of PWD, the organization has its recruitment process hindered. Besides these barriers to recruitment, the other barrier is cultural, because only a decade ago the city of Três Rios (RJ) began to receive industries from various sectors, due to a City Hall policy of tax incentives for the industrial sector.

Before this fact, what predominated in the city and still remains with great relevance is the trade sector, i.e., there is a local culture of workers that many still prefer to work in the trade sector in favor of the industrial sector. As a consequence of the foregoing considerations, one notices a low retention of PWD in the industrial sector, showing that retention practices should be adopted.

In general terms, it can be seen that the organization still does not use, as a people management strategy, an effective inclusion program. It is observed in the results of the study that the company still needs to improve its work environment with regard to accessibility, retention and awareness (training and coexistence) of PWD. 
However, the recruitment and selection practices, health assessment, and the possibility of career advancement performed by the company are still satisfactory, even if within some limitations. Despite the existence of factors that contribute to a high turnover of PWD, there is the provision of information about promotions, equality perspective and the intention to promote, expand and offer the same opportunities in relation to career for all employees, having all the same opportunity for growth in the organization.

Because the study was conducted in only one organization, it is not possible to generalize its results, but it is suggested that research be conducted in other companies in the municipality of Três Rios (RJ) in order to contribute to the validation, or not, of the results described here in relation to the process of inclusion of PWD in other companies that are also subject to the Federal Law number 8,213 (Quotas Law).

\section{REFERENCES}

Bardin, L. (1977) Análise De Conteúdo. Lisboa: Edições 70.

Boni, V.; Quaresma, J. L. Aprendendo (2005) A Entrevistar: Como Fazer Entrevistas Em Ciências Sociais. Florianópolis: Revista Em Tese, V. 2, N. 1, P. 68-80. Retrieved from https://periodicos.ufsc.br/index.php/emtese/article/view/18027

Brasil. (1989) Decreto 3298, De 20 De Dezembro De 1999. Regulamenta A Lei No 7.853, De 24 De Outubro De, Dispõe Sobre A Política Nacional Para A Integração Da Pessoa Portadora De Deficiência, Consolida As Normas De Proteção, E Dá Outras Providências. Disponível Em: Retrieved from <Http://Www.Planalto.Gov.Br/Ccivil_03/Decreto/D3298.Htm>. Available At: < Http://Www.Planalto.Gov.Br/Ccivil_03/Decreto/D3298.Htm>. Accessed 12 Oct. 2019

Campos, J. G. F.; Vasconcellos, E. P. G.; Kruglianskas, G. (2013) Incluindo Pessoas Com Deficiência Na Empresa: Estudo De Caso De Uma Multinacional Brasileira. Revista De Administração, V. 48, N. 3, P. 560-573. Retrieved from https://doi.org/10.5700/rausp1106

Chiavenato, I. (2017) Gestão De Pessoas. $3^{2}$ Edição. Rio De Janeiro: Elsevier Editora Ltda.

Freitas, M. N. C. (2009) Inserção E Gestão Do Trabalho De Pessoas Com Deficiência: Um Estudo De Caso. Curitiba: Revista De Administração Contemporânea, V. 13, N. Spe, P. 121-138. Retrieved from https://doi.org/10.1590/S141565552009000500009

Fávero, E. A. G. (2007) Direitos Das Pessoas Com Deficiência: Garantia De Igualdade Na Diversidade. 2. Ed. Rio De Janeiro: Wva.

Gaudenzi, P.; Ortega, F. (2016) Problematizando O Conceito De Deficiência A Partir Das Noções De Autonomia E Normalidade. Ciênc. Saúde Coletiva [Online], Vol.21, N.10, P. 3061-3070. Retrieved from https://doi.org/10.1590/1413812320152110.16642016

Godoy, A. S. (1995) Pesquisa Qualitativa: Tipos Fundamentais. Revista De Administração De Empresas, V. 35, N. 3, P. 20-29. Retrieved from https://doi.org/10.1590/S0034-75901995000300004

Ibge. (2018) Pessoas Com Deficiência. Retrieved from < Https://Educa.Ibge.Gov.Br/Jovens/Conheca-O-Brasil/Populacao/20551Pessoas-Com-Deficiencia.Html>. Accessed 13 Sep. 2019. 
Lancillotti, S.S.P. (2003) Deficiência E Trabalho: Redimensionando O Singular No Contexto Universal. Campinas, Sp: Autores Associados.

Malhotra, N. K. (2001) Pesquisa De Marketing. $3^{\circ}$ Edição, Editora Bookman. São Paulo.

Moreira, D. A. O (2002) Método Fenomenológico Na Pesquisa. São Paulo: Pioneira Thomson.

Neves-Silva, P.; Prais, F. G.; Silveira, A. M. (2014) Inclusão Da Pessoa Com Deficiência No Mercado De Trabalho Em Belo Horizonte, Brasil: Cenário E Perspectiva. Rio De Janeiro: Ciênc. Saúde Coletiva, Vol.20, N..8, Aug. P. 2549-2558. Retrieved from https://doi.org/10.1590/1413-81232015208.17802014

Palacios, A.; Romañach, J. (2006) El Modelo De La Diversidad. La Bioética Y Los Derechos Humanos Como Herramientas Para Alcanzarla Plena Dignidad En La Diversidad Funcional. Madrid: Ediciones Diversitas-Aies.

Relação Anual De Informações Sociais (Rais). (2018). Profissionais Com Deficiência Seguem À Margem No Acesso Ao Trabalho. Retrieved from Https://Www.Camarainclusao.Com.Br/Sem-Categoria/Rais-2018-

Profissionais-Com-Deficiencia-Seguem-A-Margem-No-Acesso-Ao-

Trabalho/> Accessed 13 Oct. 2019

Schwarz, A.; Haber, J. Cotas (2009): Como Vencer Os Desafios Da Contratação De Pessoas Com Deficiência. São Paulo: I.Social.

Tanaka, E.; Manzini, E. (2005) O Que Os Empregadores Pensam Sobre O Trabalho Da Pessoa Com Deficiência? Rio De Janeiro: Rev. Bras. Educ. Espec. Vol.11, N.2, P. 273-294. Retrieved from https://doi.org/10.1590/S141365382005000200008

. População No Último Censo. 2018. Population At The Last Census. 2018. Retrieved from Https://Cidades.Ibge.Gov.Br/Brasil/Rj/TresRios/Panorama>. Accessed 15 Nov. 2019.

. Lei N8.213/91 De 24 De Julho De 1991. Dispõe Sobre Os Planos De Benefício Da Previdência Social E Dá Outras Providências. Portal Da Legislação Planalto 1991, Jul 25. Disponível Em: Retrieved from <Http://Www.Planalto.Gov.Br/Ccivil_03/Leis/L8213cons.Htm>. Accessed 20 Sep. 2019 